\title{
Counter Terrorism : Case Study On The Radicals Religious Group
}

\author{
Eko Rubiyanto ${ }^{1}$ and Munsharif Abdul Chalim ${ }^{2}$
}

\begin{abstract}
This research aims to explore counter terrorism: a case study of radical religious group. This research used the normative juridical approach. Data collection techniques using data reduction, data presentation, triangulation and conclusion. The results showed that the group of religious radicalism in the jurisdiction of Bekasi police pioneered by asatidz or Imam FPI called for promotion of hatred toward religious groups. The media used in the spread of religious radicals in Bekasi Police Jurisdiction is through social media with the modus operandi of instilling the idea that Islamic law is the most correct. In recruiting, there are several methods used, including the cadre, mentoring, and mastery of places of worship with the main target is the younger age groups. Flourishing of religious radicalism caused by several factors, among others. Bekasi location of the region as a buffer capital city of Jakarta, the lack of supervision of the police, the involvement of religious leaders, the low education level of the community, as well as the economic conditions of the needy. Policing is done by Bekasi policecurrently done with prevention efforts, either through counseling activities, socialization, door to door system, coordination with Tomas, Toda, or Toga, as well as joint meetings FKUB about the dangers of radicalism and terrorism. The effort is still deemed less effective, so the Bekasi police in the future in the fight against terrorism must be put forward Counter Radicalization and Deradicalisation to strengthen four pillars of nationhood.

Keywords: Radicalism; Terrorism; Religion.
\end{abstract}

\section{Introduction}

Phenomenon understanding of religious radicals be an important focus in this study, because of the phenomenon understanding of religious radicalscould impact on the security situation and order in the community, even nation-state became the principal task of the Police. In fact, religious radicalism also put members of the police as a target, as well asassault against two members of the Mobile Brigade who are conducting security Ops Ramadniya Jaya in 2017 when completed the evening prayers at the Falatehan mosque at Peruri Houses JI. Palatehan Raya No. 10 Kebayoran Baru, South Jakarta. Facts gathered by the authors of the intelligence estimate contingent (Kirjen) Satintelkam Bekasi police linked to the existence of organizations or a group of supporters of religious radicalism, shows that the movement of religious radicalism is still rife, as does the presence of Gerakan Indonesia Shalat Subuh (GISS), chaired by Muhammad Al Khaththat who is General Secretary of the Muslim Forum (FUI) and the Chairman of the Action Bela Islam 313've secured related alleged treason. GISS often held Tabligh Akbar with a provocative lecture contents and discredit the government that could lead to anarchy. GISS also did not hesitate to make sweeping to

\footnotetext{
1 Student of Masters (S2) of Law Faculty of Law Unissula Semarang e-mail: ekorubiyanto2930@gmail.com

${ }^{2}$ Lecturer of Faculty of Law UNISSULA Semarang
} 
entertainment, spa and sauna, massage parlors and shops which selling alcohol to measures to impose anarchist, desire, and religious ideals with street violence.

Increased religious radicalism much rooted in reality increasingly widespread interpretation, understanding, flow, even sects within (intra) one particular religion. Among Muslims, religious radicalism was sourced from religious understanding literal, bits and pieces of the verses of the Qur'ran, reading one of the history of Islam combined with the idealization of overreaction to Islam at some period, and the deprivation of political, social and economic surviving in society.

Efforts to prevent the danger of radicalism in Bekasi through policing by the Bekasi police are still being conducted. ${ }^{3}$ This is in accordance with Article 19 paragraph (I) of the Constitution of the Republic of Indonesia Number 2 Of 2002 on the Indonesian National Police, which mandates that "in carrying out its duties and authorities, the Indonesian National Police officers always act based on legal norms and heed the norms of religion, decency, morality and upholding human rights; and Article 19 paragraph (2) of the Constitution of the Republic of Indonesia Number 2 Of 2002 on the Indonesian National Police"in carrying out the duties and authority as stipulated in Article 19 paragraph (I), the Indonesian National Police prioritize preventive measures. ${ }^{4}$

In accordance with the Chief of Police Priority Program III, namely "Pro Radical Group Handling Violence and Intolerance Greater Optimal", The police tried to improve the detection of early detection and action in order mapping pro radical violence and intolerance. The police were also trying to build the cease-and-desist power of citizens to various forms of threats radical groups pro violence and intolerance. Efforts are made to develop cooperation with relevant stakeholders or intensify dialogue in the pockets of radical pro-violence and intolerance.

Police efforts in the fight against the spread of radical religious in Bekasi Police Jurisdiction is basically supported by the President Ir. Joko Widodo (Jokowi). The administration of President Jokowi explicitly trying to maintain diversity and nationality, as well as promoting tolerance and civil rights community that has been marred by a number of radical-intolerant with the issuance of Government Regulation in Lieu of Law (Perpu) of the Republic of Indonesia Number 2 Of 2017 on the Amendment of the Republic of Indonesia Number 17 of 2013 on Civil Society Organizations. The Government of Indonesia has dissolved at least six organizations that are considered in violation of the spirit and values of Pancasila and the 1945 Constitution. ${ }^{5}$

Bekasi police basically beenprevention efforts and law enforcement to the threat of religious radicalism. Each function has been trying to animatespirit of policing as the responsibilities of each function in the Police as carrier community policing to prevent understanding of religious radicals in Bekasi. However, understanding the

\footnotetext{
${ }^{3}$ Law of the Republic of Indonesia Number 2 Of 2002 on the Indonesian National Police, Article 19.

${ }^{4}$ Suparmin, 2012, Model Pemolisian Pendamai: Dari Perspektif Alternative Dispute Resolution (ADR) (Studi Penyelesaian Konflik antar Partai Politik). Foreword: Prof. Dr. Muladi, S.H. Semarang: Badan Penerbit Universitas Diponegoro Semarang, p.10.

${ }^{5}$ Government Regulation in Lieu of Law (Perppu) of the Republic of Indonesia Number 2 Of 2017 concerning the Amendment Law of the Republic of Indonesia Number 17 of 2013 on Civil Society Organizations.
} 
development of religious radicals in the jurisdiction of Bekasi police is still ongoing which would threaten security and stability.

Based on the problems presented above, the formulation of the problem in this research is "How policing in the prevention of Islamic radicalism in Bekasi Police Jurisdiction?" Based on the formulation of the above problems, research questions that will be answered in this study are:

1. How do the characteristics of religious radicalism group in Bekasi Police Jurisdiction?

2. What are the factors that encourage the growth and development of radical religious groups in Bekasi Police Jurisdiction?

3. How policing is conducted by the Bekasi police today and the future?

\section{Methods}

The research method is an attempt to discover, develop, and test the truth of knowledge by means of scientific methods. Therefore, the research methods used should be appropriate. Research methods in legal research is a normative juridical approach. Source of data used in the study can be distinguished to primary legal materials, secondary legal materials, tertiary legal materials. Data collection techniques using data reduction, data presentation, triangulation and conclusion.

\section{Results And Discussion}

\subsection{Characteristics Group Religious Radicalism in Bekasi Police Jurisdiction}

The group of religious radicalism in Bekasi Police Jurisdiction pioneered by asatidz or Imam FPI such as Habib Rizieq Shihab calling for promotion of hatred toward a particular religious group. The group members of religious radicalism in Bekasi Police Jurisdiction has different characteristics with the general public, such as:

- Physically : Special Perfoma, extreme, rigid, high fanaticism, tolerance is low; Often speechless "Khafir, anti-Islam, Suicide, Allahu Akbar, jihad, caliphate, Heaven, Angels"

- Tenets / ideology : Flow / understanding of the religion professed ideology finals in life; The values adopted directly from the original source, absolutely rule out the times and science and technology; Texbook pure understanding and fear of heresy. The group considers the most true, others false.

- Activity; Proprietary, closed, secret ; This movement usually is often at odds with the wider community, including governments.

The spread of radical happens in Bekasi Police Jurisdiction is essentially motivated by a desire to enforce Islamic law. This also occurs in cases of terrorism that happened before, as is the case with the bombing carried out by Ali Imron and Umar Patek. Based on previous research conducted by Gunaratna and Hennessy, it is known that there are a variety of reasons and motivations of Ali Imron and Umar Patek to join and 
fight for Jemaah Islamiah (J). ${ }^{6}$ Associated with the ideology which they have seen, the two actors that know what the purpose of ideology, but basically do not understand the true meaning of ideology. Umar Patek understand jihad as "applying Islamic law in a serious, firm and consistent in one place by a nation known." According to the Umar Patek, if Muslims can implement Islamic law in the country without fighting, it is also said to be a jihad. For Umar Patek, personal identity is important and he clearly identified himself as a mujahid and not jihadi. On the one hand, Ali Imron interpret jihad as "war", although Ali Imron also admitted that none of the interpretations of the Qur'an. Ali Imron believes that jihad is liable to life in accordance with the teachings of Islam.

An ideology, is needed by a nation to bind the people to live together in the shade of an ideology. Likewise with Indonesia that the founding fathersnya already stipulated Pancasila as an ideology of the Indonesian nation, it automatically Pancasila as an ideology it must be obeyed and followed by the entire nation. Pancasila ideology with the principle of unity in diversity taught us to always live with a sense of tolerance. Because of the many varieties of religious, racial and flow, but the essence is one also, which is one of the nation, the nation of Indonesia.

Lately appeared a new ideology in Indonesia, which is very disturbing society, namely the ideology of radical Islam. An exclusive ideology that always puts the violence in the realization of its objectives. Dogmas that exist in the teachings of the Islamic religion and what is interpreted narrowly and be misused to legitimize their over all radical action. The ideology of radical Islam is very much influenced by the ideology of ISIS or the Islamic State in Iraq and Syria, which is a group of militant jihad idiologinya being developed all over the world through websites, books, education in schools, universities, lecture, social networks like facebook, you tube, twitter etc., until its influence to Indonesia.

The spread of radical happens in Bekasi Police Jurisdiction is essentially motivated by a desire to enforce Islamic law. This also occurs in cases of terrorism that happened before, as is the case with the bombing carried out by Ali Imron and Umar Patek. Based on earlier researchnoted that there are a variety of reasons and motivations of Ali Imron and Umar Patek to join and fight for Jemaah Islamiah (JI). ${ }^{7}$ Associated with the ideology which they have seen, the two actors that know what the purpose of ideology, but basically do not understand the true meaning of ideology. Umar Patek understand jihad as"apply Islamic law in a serious, firm and consistent in one place by a nation known. "According to the Umar Patek, if Muslims can implement Islamic law in the country without fighting, it is also said to be a jihad. For Patek, personal identity is important and he clearly identified himself as a mujahid and not jihadi. on the one hand, Ali Imron interpret jihad as "war", although Ali Imron also admitted that none of the interpretations of the Koran. Ali Imron believes that jihad is liable to life in accordance with the teachings of Islam.

\footnotetext{
${ }^{6}$ Gunaratna, Rohan., dan Hennessy, Orla, "Counter Terrorist Trends and Analysis. International Centre for Political Violence and Terrorism Research". Volume IV: Issue. 9. School of Nanyang Technological University, (2012)url :. http://www.rsis.edu.sg/research/icpvtr/ctta/

${ }^{7}$ Ibid, p.128.
} 
The asatidz or Imam FPI one of them Habib Rizieq Shihab in a pitched preaching confrontational and containing expressions of hostility to certain religious groups in Tabligh Akbar in Sukaresmi Village, South Cikarang is one effort to instill a false ideology. Jihad as a way of God is something that is justified, in any way, including with the bombing. Deployment the spread of radical ideologism by asatidz or Imam FPI of Bekasi Police Jurisdiction is the culprit because it can cause a false understanding of the meaning of jihad, so that the bomb threats can be increased and become a real nuisance in public life.

According to the analysis the authors on the study findings, radikalisme Islam in particular carried out by radical Islamic organizations like HTI involves two factors at once the religious factor and factor social. HTI as a radical organization that began to strengthen in the cities great with most young sympathizers and student, found that $\mathrm{HTI}$ has a distinctive pattern in build knowledge of sympathizers; which begins by presenting various cases of social inequality, then followed by stating that the root of all inequality is due to the practice of an infidel, secular or other not the Islamic system, then topped with a solution and is the only solution to overcome all imbalances The implementation of the system is the (law) of Islam.

The group of religious radicalism in the further spread of radical and recruiting members have taken advantage of the development of information and communication technology. Previous research also found that the spread of religious radicalism is done via the internet. Laptops are secured from the perpetrators of the spread of the religious radical is a means to recruit or embed the mistaken belief that violent jihad is a command of God. Destination sites Islamic jihad is built is that Muslims understand the meaning and nature of jihad, then got out of sitting down together to struggle to enforce Islamic Sharia in all aspects of life, so that the Islamic Sharia as a reference only to the system of governance and policy state nationally and internationally. What is meant by the Islamic law here is, all the rules of life as well as the guidance provided by religion Islam derived from the Qur'an and the Sunnah of the Prophet Muhammad Saw. ${ }^{8}$

Analysis of researchers based on previous research, an outline of the method the spread of radical religious in Bekasi Police Jurisdiction is done by the cadre, mentoring, and mastery of places of worship. Cadre organization is building activities to members and prospective members of the organization or investigator or bearers of radicalism. ${ }^{9}$ The first internal cadre. Internal cadre training is usually done in the form of prospective new members and old members of coaching. Recruitment of prospective new members is done either individually or in groups. Individual recruitment is usually done by Islamic radical underground organization through what is commonly referred to brainwashing. Teaching activities organized by groups radical also contains understandings of Islam that is loaded with charge of radicalism, such as the suggestion to antagonize the other party wrapped considered contrary to the concept of al-wala wa al-bara. Brainwashing can be done directly through the recitation, or indirectly, through the deployment of a book or Web site that radicalism.

\footnotetext{
${ }^{8}$ Munip, A. 2012. Menangkal Radikalisme Agama di Sekolah. Jurnal Pendidikan Islam. Vol. 1. No. 2: 159181. Program Pascasarjana UIN Sunan Kalijaga Yogyakarta.

${ }^{9}$ Ibid, p.176.
} 
Second, mentoring Islam. At first, the Islamic mentoring activities carried out in several campus Public Higher Education and is intended as a complement or complementary activities to cope with the limited time PAI learning activities in the classroom. Today, the Islamic mentoring activities can also be seen in some high schools (SMA / SMP). Typically, the trainers (often called a mentor or murabbi) derived from class older siblings or outsiders who deliberately imported. PAI mentoring activities at school and in college is often used by his mentor to the teachings of Islam charged radicalism.

Third, mastery of places of worship. Through mosques successful "overpowered", Radical Islamic groups in Bekasi Police Jurisdiction very astute utilize less mosque "be managed" by the surrounding community. Management of an abandoned mosque in Bekasi Police Jurisdiction will rise to the spread of radical. People who become worshipers at the mosque will be brought to an ideology that everything that is not in accordance with Islamic law is wrong and must be fought.

Funding of terrorism is any act in order to provide, collect, give, or lend funds, either directly or indirectly, with the intent to be used and / or known to be used to carry out terrorist activities, terrorist organization or a terrorist. ${ }^{10}$ Funding system radical groups that carried out through compulsory contributions or donations from the volunteers or members of a way to do in order to fool law enforcement officers. The collection of these funds are also made directly without any evidence of the transfer. Police in this case of Bekasi police already should be disclosure of the persons, groups or organizations that provide funding. That is because the dissolution of funding can minimize the growing understanding of radical and terrorism. It needs to be the attention of the leadership, because the Bekasi police also supported by Chapter III Article 4, Article 5, Article 6 and Article 8 by Act No. 9 of 2013 on the Prevention and Eradication of the Financing of Terrorism.

\subsection{Factors That Encourage Growth and Development of Radical Religious Groups in The Bekasi Police Jurisdiction}

Growth and development of radical religious groups in Bekasi Police Jurisdiction can not be separated from Bekasi geographical conditions as the buffer area of the capital. Bekasi strategic layout as buffer capital Jakarta to be a factor that encourages growth and development of radical understanding in Bekasi Police Jurisdiction. Kota Bekasi Police Jurisdiction is one area in Indonesia that have high levels of vulnerability to the threat of radical religious understanding is quite high. It is not independent of the demographics of the area of Bekasi which is a buffer zone of the capital. As the region immediately adjacent to the capital, Bekasi is often a place of transit or a place for radical groups to recruit or develop plans for raising hell.

Movement of religious radicalism in Indonesia and particularly in the area of Bekasi police law, if viewed from the perspective of social science actually does not appear on the actual religious entity as esoteric beliefs and promoting peace. Movement radicalisms religion is a reaction of disappointment and unusage individual or group to modernity and secularization or diplomacy parliament failed in achieving the goals of

\footnotetext{
${ }^{10}$ Law of the Republic of Indonesia Number 9 of 2013 on the Prevention and Eradication of Terrorism Financing Chapter I Article 1 (1).
} 
power (politics) and economy, or in other words as a form of escape on how to interact and communicate that arise from cause culture shock.

Radicalism in this era are no longer nuanced politics of East-West rivalry, but more due to the differences and ideological rivalry, especially in this case, he sees Islam has the potential to collide directly with the West. ${ }^{11}$ How to view, vote to the Huntington's thesis about Islam as an ideology that is dangerous for the world civilization.

Islam and Western civilization is the possibility of conflict, because Islam itself which is believed to want to unify his view of religion and state / politics, especially understand fundamentalism, although this understanding is not just the only one who believes that. This view is the mainstream view in Islam According to Huntington, Muslims consider that their cultures are very different from Western culture. The main problem for the West is not Islamic fundamentalism but Islam itself, a different civilization and his people believe in the superiority of the other civilizations. Meanwhile Huntington believes that the synthesis between Islamic sentiment and the idea that the state is not possible. ${ }^{12}$ The society's perspective on the modern era were easily provoked by the conflict in the name of religion, especially Islam can enrich the growth of radicalism in Bekasi Police Jurisdiction.

Target the spread of radical religious in Bekasi Police Jurisdiction on young people is inseparable from the individual characteristics. Adolescence show clearly the properties of transition or transition. Most people assume that adolescence is a critical period in human life, because in this period there is a change of physical, psychological, attitudes, and emotions. This period is also said to be a period full of challenges, which sometimes creates problems vary because at this time a teenager was trying to reach the maturity of personality development by identifying, adjust, accept and respect themselves. ${ }^{13}$ Adolescence is a thirst for knowledge is often lost with the teachings of radical obtained through social media. Bekasi police already should be made a real effort in the prevention of radical understanding that puts young people as targets.

Many Muslim leaders were identified as leaders or members Komando Jihad were arrested and detained. This is consistent with previous studies showing that religious leaders today no longer speak of God, but rather talk"in the name of God" or even be "God funnel" to convey moral messages on the earth. ${ }^{14}$ It is quite dangerous because when the affair between religion and power, then what emerges is authoritarianism or arbitrariness of the authorities. Religious leaders in Bekasi Police Jurisdiction, as well as Habib Rizieq Shihab blatantly inciting citizens to act radically. FPI leader Habib Rizieq Shihab also has clearly demonstrated acts of violence in the name of Islam.

Economic and political factors are the two factors often intervene in religious life. True religion is a matter of political morality and economics is an issue that the profane. Both must be placed in a different area. Economic factors are limited, often a driver of Bekasi District residents to join a radical group or terrorism. The desire to get a better

\footnotetext{
${ }^{11}$ Bayley, David H., dan Weisburd, David. 2007. The Role of the Police in Counterterrorism. New York: Springer Verlaag..

12 lbid, p.245.

${ }^{13}$ Monks, F. J., knoers, A.M.P., dan Haditono, S.R. 2002. Psikologi Perkembangan: Pengantar dalam Berbagai Bagiannya. Yogyakarta: Gadjah Mada University Press.

14 Saifuddin. 2011. Radikalisme Islam di Kalangan Mahasiswa (Sebuah Metamorfosa Baru). Analisis, Volume XI, Nomor 1. Universitas Islam Negeri Sunan Kalijaga Yogyakarta.
} 
life for the family members getting citizens to join radical groups and terrorism. According to the analysis the authors, should policies and measures aimed at prevention and destruction to maintain a balance in the obligations to protect the sovereignty of the state, rights of victims and witnesses, as well as the rights of suspects, and defendants. The previous study explains that most observers believe that the roots of Islamic radicalism is the economic factor. Esposito and Voll says that Islamic militancy in Europe associated with the presence of the youth, the unemployed, and the homeless, who then recruited Islamists. ${ }^{15}$ Anderson also thinks that Islamic militancy in the Middle East dealing with the economic difficulties experienced by the Arab countries when the economic relationship with Moscow broke up after the Soviet Union fell in 1991. Euben show that violent Islamic fundamentalists associated with frustration as a result of modernization which is indirectly positioned Muslims are the lowly position of the working class. This is a dilemma when there are people in Bekasi who are members of radical and terrorist groups. On the one hand Bekasi is the largest industrial center in the Southeast Asia region. Employment is also open to residents in Bekasi. It is a proof that the uneven economic conditions in Bekasi.

\subsection{Policing Performed by Bekasi police}

Based on the findings of this research is that policing is done by the Bekasi police in preventing the growing development of radical understand more emphasis on preemptive and preventive measures. Although repressive measures continue to be implemented. Primary prevention in the world of criminal justice is to identify the physical and social environment that allows the opportunity to or accelerate the occurrence of crime. $^{16}$ Which included herein are environmental planning, environmental observation, general prevention, personal security, education about crime and crime prevention. Crime prevention efforts are implemented with the aim to avoid becoming a victim of crime is an effective means for the reduction in crime and fear of crime.The success of this primary crime prevention approach depends heavily on community participation. To be able to resist the development of a radical understanding in Bekasi Police Jurisdiction, various forms of activities undertaken by the Bekasi police Binmas function is intended in order to create a positive partnership, so that people will be together with the police in the fight against radical religious understanding. Partnerships with community activities, but aims to raise awareness of community law, also intended for the public also has a cease and desist power to various forms of incitement so that the people involved in the movements that base ons radicalism. Efforts are made todo a safari and meeting with religious leaders to convey a message of social order to mosques and pockets of people who indicated strong spread of radical.

To realize the sense of security it is impossible to do by the police alone, it is impossible to do with ways of acting police conventional by bureaucracy, have been

\footnotetext{
15 Nurjannah. 2013. Faktor Pemicu Munculnya Radikalisme Islam Atas Nama Dakwah. Jurnal Dakwah, Vol. XIV, No. 2. Fakultas Dakwah dan Komunikasi UIN Sunan Kalijaga Yogyakarta.

${ }^{16}$ Lab, Stephen P. 2006. Crime Prevention: Approach, Practice, and Evaluation. $7^{\text {th }}$ edition. CRC Press.
} 
impossible through commands centralized regardless of local conditions are very different from the one with another place. ${ }^{17}$ Community-oriented policing is necessary to "An equal commitment to community-oriented government-Community-oriented government adapts the principles of community policing to the delivery of municipal services to neighborhoods", ${ }^{18}$ Polres serve as the basis for the operational command of a police force that's leading and most complete element or function and its parts. With the basic operational command at the police station level means the authority or autonomy of the Police to provide excellent service to the community, and can develop a variety of creativity and innovation in solving various social issues or working with local communities to maintain security and order. In the implementation of community policing in order to combat religious radicalism, Bekasi police attempted to provide excellent service to the community for the creation of Kamtibmas. Efforts made in preventive policing understand religious radicals is to promote community policing.

Community policing in essence a joint effort to identify, define, and anticipate the various issues that arise in the governance of community life in connection with the development process that is sustainable. ${ }^{19}$ Further described in Article 1 paragraph 2 Police Regulation No. 3 of 2015 on Community Policing stated that: ${ }^{20}$ Community policing hereinafter referred to as community policing is an activity to engage the community through partnerships members of the police and the community, so as to detect and identify the problems of security and public order (internal security) in the environment and find the problem.

Bekasi police through Bhabibkamtibmas in execution policing in the fight against religious radicalism has been basically guided Police Regulation No. 3 of 2015 on Community Policing. Bhabinkamtibmas of Bekasi with various obstacles encountered in the implementation of policing, not cease to invite the community to prevent people from easily influenced understand the religious radicals. Policing functions through partnerships in the context of the maintenance of social order. Bhabinkamtibmas of Bekasi also seeks to help communities overcome the social problems in their environment. Collaborative efforts such as the joint coordination FKUB to spread the brochure reject radicalism and terrorism continue to be put forward for detecting, identifying, analyzing, set priority issues and formulate kamtibmas problem solving. From a series of these actions is expected to awareness and public awareness / community against potential threats / security problems, order and safety in the environment can be increased. Communities will increasingly have the ability to identify the root of the problems that occur in the environment, including the problem of rampant spread of religious radicalism in Bekasi Police Jurisdiction.

\footnotetext{
${ }^{17}$ Bayley David H , 1994, Police for the Future (diterjemahkan dan disadur oleh Kunarto). Jakarta: Cipta Manunggal._ https://polmas.wordpress.com/2014/10/27/pemolisian-komuniti-community-policingdalam-menciptakan-kamtibmas/.

${ }^{18}$ Trojanowicz Robert, 1998. Community Policing: How To Get Started, co-authored with policing.coms Bonnie Bucqueroux, Anderson Publishing, Cincinnati, $\mathrm{OH}$.

${ }^{19}$ Soedarsono, T. 2015. Natralis : Beberapa Saran Hukum dalam Upaya Pembangunan Sistem Hukum Nasional. Jakarta: PT. Gramedia.

${ }^{20}$ Police Regulation No. 3 of 2015 on the Community Policing Article 1 paragraph 2
} 
Police science is the study of social problems and handling. ${ }^{21}$ Police Science helpful in solving problems, making it useful for humans. Solving the problem in question is to the safety aspects, even certain that every problem has two aspects, namely the security and well-being. ${ }^{22}$ The operational activities are managed using strategies that are tailored to the escalation of the social problems encountered, as reviewed in Iceberg Theory. ${ }^{23}$ In the context of police science, strategy undertaken by Bekasi police basically included into the strategy of the Iceberg Theory in addressing social problems. Polres Metro Bekasi through SatBinmas put forward the strategy of early detection functionality and pre-emptive and preventive function strategy -prevention (direct prevention). Their activities with elements of society may affect the ability of Bekasi police in identifying the spread of radicalism, so it has the right strategy in the fight against religious radicalism in Bekasi Police Jurisdiction.

\section{Closing}

\subsection{Conclusion}

- The group of religious radicalism in the Bekasi Police Jurisdiction pioneered by asatidz or Imam FPI called for promotion of hatred toward religious groups. Group members of religious radicalism in Bekasi Police Jurisdiction has exclusive features, including a special appearance, calls on religious and groups that do not consider Shari'a compliant Islamic religion is wrong and must be fought. The ingredients used in the spread of religious radicals in Bekasi Police Jurisdiction is through social media (Facebook, Twitter, Instagram, Website) through the study on halaqahhalaqah well closed in mosques, college or office. Modus operandi of radical religious groups in recruiting members is to instill the idea that Islamic law is the most correct. Target of recruitment by groups of religious radicalism is juvenile and lay people in religion. In recruiting, there are several methods used, including the cadre, mentoring, and mastery of places of worship. Although the group of religious radicalism has not shown acts of terror, such as the bombing but a serious threat to internal security situation,

- Factors that encourage growth and development of radical religious groups in the jurisdiction Bekasi police can be classified into internal factors and external factors. Internal factors derived from the lack of control by Bekasi police against groups of religious radicalism. External factors, including the location of the region as a buffer Bekasi regency capital city of Jakarta, the involvement of religious leaders, the low education level of the community, as well as the economic conditions of the needy.

- Policing is done by Bekasi policecurrently done with prevention efforts, either through counseling activities, socialization, door to door system, coordination with Tomas, Toda, or Toga, as well as joint meetings FKUB about the dangers of

\footnotetext{
${ }^{21}$ Dahniel, Rycko Amelza, et.al. 2015. Ilmu Kepolisian. First Edition $69^{\text {th }}$ Anniversary STIK-PTIK. Jakarta: PTIK Press.

${ }^{22}$ Fadillah, S. F., dan Machyawaty, T. 2015. Lex Specialis Ilmu Kepolisian. Tangerang: Faris Vania Publishing.

${ }^{23}$ Op.cit, Dahniel, et al, 2015
} 
radicalism and terrorism. Bekasi police basically have also been supported by the policing budget radicalism and terrorism prevention. Bekasi police in the fight against religious radicalism in the future should be more forward step Counter Radicalization and Deradicalisation. It should be emphasized considering that Bekasi police still seem to wait the occurrence of acts of religious radicalism, such as sweeping conducted by FPI. De-radicalization in the field of education should be further emphasized by strengthening its four pillars nationality, Pancasila, National Unity, the Homeland, and UUD 1945.

\subsection{Suggestion}

Bekasi police in order to implement measures Counter Radicalization and Deradicalisation in policing prevention of religious radicalism, De-radicalization in the future by the Bekasi police should involve various elements, both side institutions such as telecommunications providers, Army, Department of Education, or the elements of society. Deradicalisation important to be done earlyby instilling a spirit of nationalism and love of the Homeland in coordination with the Department of Education in order to prevent the younger generation from the influence of religious radicalism.

\section{Bibliography}

[1] Bayley David H , 1994, Police for the Future (diterjemahkan dan disadur oleh Kunarto). Jakarta: Cipta Manunggal. https://polmas.wordpress.com/2014/10/27/pemolisian-komuniti-communitypolicing-dalam-menciptakan-kamtibmas/.

[2] Dahniel, Rycko Amelza, et.al. 2015. Ilmu Kepolisian. Edisi Perdana Dies Natalis ke69 STIK-PTIK. Jakarta: PTIK Press.

[3] Fadillah, S. F., dan Machyawaty, T. 2015. Lex Specialis Ilmu Kepolisian. Tangerang: Faris Vania Publishing

[4] Gunaratna, Rohan., dan Hennessy, Orla, "Counter Terrorist Trends and Analysis. International Centre for Political Violence and Terrorism Research". Volume IV: Issue. 9. School of Nanyang Technological University, (2012)url :. http://www.rsis.edu.sg/research/icpvtr/ctta/

[5] Monks, F. J., knoers, A.M.P., dan Haditono, S.R. 2002. Psikologi Perkembangan: Pengantar dalam Berbagai Bagiannya. Yogyakarta: Gadjah Mada University Press.

[6] Munip, A. 2012. Menangkal Radikalisme Agama di Sekolah. Jurnal Pendidikan Islam. Vol. 1. No. 2: 159-181. Program Pascasarjana UIN Sunan Kalijaga Yogyakarta.

[7] Nurjannah. 2013. Faktor Pemicu Munculnya Radikalisme Islam Atas Nama Dakwah. Jurnal Dakwah, Vol. XIV, No. 2. Fakultas Dakwah dan Komunikasi UIN Sunan Kalijaga Yogyakarta.

[8] Lab, Stephen P. 2006. Crime Prevention: Approach, Practice, and Evaluation. $7^{\text {th }}$ edition. CRC Press. 
[9] Saifuddin. 2011. Radikalisme Islam di Kalangan Mahasiswa (Sebuah Metamorfosa Baru). Analisis, Volume XI, Nomor 1. Universitas Islam Negeri Sunan Kalijaga Yogyakarta.

[10] Soedarsono, T. 2015. Natralis : Beberapa Saran Hukum dalam Upaya Pembangunan Sistem Hukum Nasional. Jakarta: PT. Gramedia.

[11] Suparmin, 2012, Model Pemolisian Pendamai: Dari Perspektif Alternative Dispute Resolution (ADR) (Studi Penyelesaian Konflik antar Partai Politik). Pengantar: Prof. Dr. Muladi, S.H. Semarang: Badan Penerbit Universitas Diponegoro Semarang.

[12] Trojanowicz Robert, 1998. Community Policing: How To Get Started, co-authored with policing.coms Bonnie Bucqueroux, Anderson Publishing, Cincinnati, $\mathrm{OH}$.

[13] Law of the Republic of Indonesia Number 2 Of 2002 on the Indonesian National Police.

[14] Law of the Republic of Indonesia Number 9 of 2013 on the Prevention and Eradication of the Financing of Terrorism.

[15] Police Regulation No. 3 of 2015 on Community Policing.

[16] Government Regulation in Lieu of Law (Perppu) of the Republic of Indonesia Number 2 Of 2017 concerning the Amendment Law of the Republic of Indonesia Number 17 of 2013 on Civil Society Organizations. 